
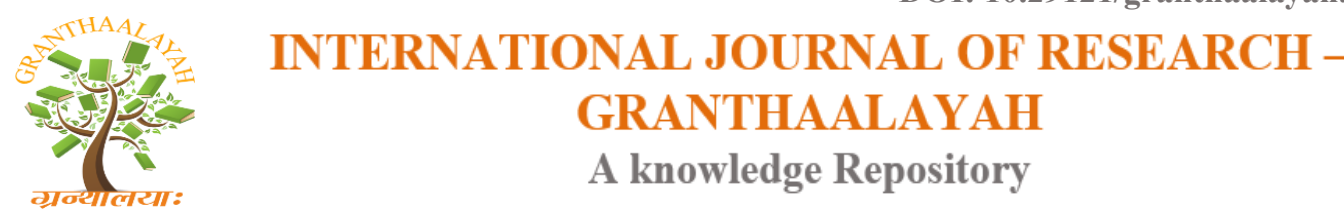

口ifing

Management

\title{
A STUDY ON IMPACT OF TELEVISION ADVERTISMENT ON CHILDREN'S ATTITUDE WITHSPECIAL REFFRENCE TO CONFECTIONARY PRODUCT IN PALAYAMKOTTAI
}

\author{
Dr. M. N. Mohamed Abusali Sheik ${ }^{* 1}$, R. Mano Juliet ${ }^{2}$ \\ ${ }^{* 1}$ Assistant Professor of Commerce, Sadakathullah Appa College, Tirunelveli, TamilNadu, \\ INDIA \\ ${ }^{2}$ M.com, M.Phil., Research Scholar, Dept of Commerce, Sadakathullah Appa College, \\ Tirunelveli, TamilNadu, INDIA
}

\begin{abstract}
In this research we investigate the impact of television advertisement on children with special reference to confectionary product in Palayamkottai. A questionnaire was used in order to collect data on impact of television advertisement on children with special reference to confectionary product different school of Palayamkottai were visited in order to collected data .The respondent agreed with this statement that there is impact of television advertisement on children with special reference to confectionary product.
\end{abstract}

Keywords:

T.V advertisement, Impact, Confectionary product.

Cite This Article: Dr. M. N. Mohamed Abusali Sheik, and R. Mano Juliet, "A STUDY ON IMPACT OF TELEVISION ADVERTISMENT ON CHILDREN'S ATTITUDE WITHSPECIAL REFFRENCE TO CONFECTIONARY PRODUCT IN PALAYAMKOTTAI" International Journal of Research - Granthaalayah, Vol. 4, No. 4: SE (2016): 59-64.

\section{INTRODUCTION}

It is more popular in India. T.V Advertisement is the latest medium of mass communication and is widely used for advertisement. It is an audio-visual medium because one can see and hear .People is impressed by pictorial presentation.

\section{CHILDREN AND T.V ADVERTISEMENT}

Today's children have a unique power in many ways from previous generation. But perhaps that most influencing on our children todays is T.V Advertisement and internet. Advertisers choose children because they are feature customers and also they are the most easily influenced and will spend their packet money if they find something interesting. Advertising to Children has long been a very successful way to build a solid consumer base that will win the mind of consumer 
purchasing. Advertising to children generate jobs, injects money into the economy and instills in children at a young age the importance of freedom of choice. It also develops a child's ability to understand the value of money.

\section{OBJECTIVES OF THE STUDY}

The objective of the study is to find out the level of influence of the children's in Palayamkottai towards television advertisement and find out the factors that influence their attitude towards television advertisement and a study on the impact of television advertisement on children with special reference to confectionary product in Palayamkottai.

\section{Sample Design}

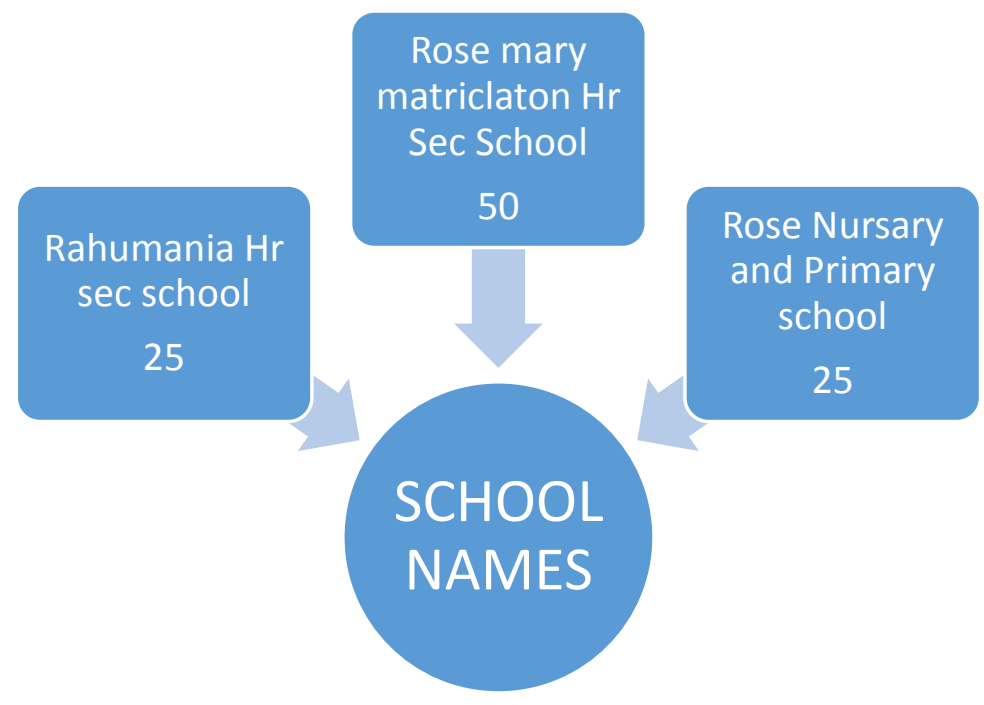

\section{Data collection}

The present study is based on both primary and secondary data required primary data were collected by using interview schedule the respondent s selected for the studies were mostly met at their school. Secondary data collected from books, journals and websites.

\section{Plan of analysis}

After collected the necessary data from the respondent, the resescher verified the data thoroughly .the collected data was tabulated and analyzed using statistical tools like percentage, chi-square test and ANOVA.

\section{ANALYSIS}

\section{Demographic characteristics of respondents}

Data for the study were gathered by primary data collected throw the interview schedule method among children from Palayamkottai.

1. Majority of the respondents (54\%) male children.

2. Majority of the respondent parent well educated graduate $(30 \%)$ post graduate $(12 \%)$ and professional course (12\%). 
3. Majority of the respondent fall in the age group of 12-14(71\%).

4. Majority of the respondent family have two children $(62 \%)$.

5. Majority of the respondent family type nuclear family $(56 \%)$.

\section{Awareness about the Television Advertisements}

- The entire respondent watching T.V Regularly.

- Majority of the respondent $82 \%$ like T.V advertisement.

- Majority of the respondent $44 \%$ on an average $1 \mathrm{hrs}$ watching T.V

- More than the half of respondent $76 \%$ watching T.V with our parent.

- More than the half of respondent $62 \%$ says watching T.V with the purpose of take a relaxation.

- More than the half of respondent $78 \%$ feels T.V Advertisement Attract to buy the product ,most of the respondent 58\% say star/models and their appearance attract more ,some of the respondent $26 \%$ say information oriented part attract more, rest of them $14 \%$ say presentation and concept advertisement part attract more.

\section{Features of T.V Advertisement}

Regarding based on the feature of advertisement in television, the current study result revealed the type of advertisement you prefer made by children's. In ranking order respondent indicate they would mostly like to watch FUNY ADVERTISMENT 54\%, ,INTERESTING and ATTRATIVE 24\%,INFOMATIVE 10\%,TECHNICAL $8 \%$, while the smallest of watch DESCRIPTIVE type of advertisement.

\section{Factors Influence in purchasing decision}

Majority of the respondent $65 \%$ says repetitive ads very influence to purchase confectionery product, $32 \%$ respondent say informative given ads less influence to purchase the confectionery product, $13 \%$ say price awareness ads very influence to purchase the confectionery product.

\section{CHI -SQUARE TEST}

\section{HYPOTHYES}

There is no significant relationship between the Age and Level of influence the T.V Ads.

\begin{tabular}{|c|c|c|c|c|}
\hline \multirow[t]{2}{*}{ AGE } & \multicolumn{3}{|c|}{$\begin{array}{l}\text { T.V ADVERTISMENT INFLUENCE } \\
\text { LEVEL }\end{array}$} & \multirow[t]{2}{*}{ TOTAL } \\
\hline & LOW & MODERTATE & HIGH & \\
\hline & $0(0.00)$ & $1(1.92)$ & $7(6.08)$ & 8 \\
\hline & $0(0.00)$ & $6(5.04)$ & $15(15.96)$ & 21 \\
\hline $12-14$ & $0(0.00)$ & $17(17.04)$ & $54(53.96)$ & 71 \\
\hline TOTAL & $\mathbf{0}$ & 24 & 76 & 100 \\
\hline
\end{tabular}


$X^{2}$ Value $=0.8208$ table value $($ at5\% $)=9.488 \quad$ D.F $=4$

Table 1 reveals that the majority of the respondent falls under the age between 12-14 years. The calculated $X^{2}$ Value $=0.8208$ he hypothesisis less than the table value (9.488)at 5\% level. Hence the hypothesis that there is no significant association between the age of the respondents and level of influence of T.V ads is accepted.

\section{Hypothesis}

There is no significant associate between the T.V viewing hours and level of influence of T.V ads.

\begin{tabular}{|l|l|l|l|l|}
\hline \multirow{2}{*}{ Tour Watching } & \multicolumn{2}{|l|}{ Level of influence of T.V ads } & \multirow{2}{*}{ Total } \\
\cline { 2 - 5 } & low & Moderate & High & \\
\hline 1 hour & $0 .(0.00)$ & $11(10.56)$ & $33(33.44)$ & 44 \\
\hline 2 hour & $0 .(0.00)$ & $5(3.60)$ & $9(11.4)$ & 15 \\
\hline 3hour & $0 .(0.00)$ & $4(6.96)$ & $25(22.04)$ & 29 \\
\hline Above 3 hour & $0 .(0.00)$ & $3(2.88)$ & $9(9.12)$ & 12 \\
\hline Total & $0 .(0.00)$ & 24 & 76 & 100 \\
\hline
\end{tabular}

$X^{2}$ Value $=3.7923 \quad$ table value $($ at $5 \%)=9.488 \quad$ D.F $=4$

Table 2 reveals that the majority of the respondents on an average 1 hour watching T.V. Calculate $X^{2}$ Value (3.7923) is less than the table value (9.488) at 5\% level .hence the hypothesis that there is no significant association between the T.V viewing hours and level of influence of T.V ads is accept .

ANOVA ON TELEVISON VIEWING HOURSE BASE

\begin{tabular}{|c|c|c|c|c|c|c|}
\hline & & $\begin{array}{ll}\text { SUM } & \text { OF } \\
\text { SQUARES } & \end{array}$ & $D F$ & \begin{tabular}{|l} 
MEAN \\
SQUARE
\end{tabular} & $F$ & $S I G$ \\
\hline \multirow{3}{*}{$\begin{array}{l}\text { COFECTNARY } \\
\text { PRODUCT } \\
\text { ADVERTISMENT }\end{array}$} & $\begin{array}{l}\text { BETWEEN } \\
\text { GRROUPS }\end{array}$ & 10.115 & 4 & 2.529 & \multirow[t]{3}{*}{6.901} & \multirow[t]{3}{*}{.000} \\
\hline & $\begin{array}{ll}\text { WITH } & \text { IN } \\
\text { GROUPS } & \\
\end{array}$ & 89.778 & 245 & .366 & & \\
\hline & TOTAL & 99.893 & 249 & & & \\
\hline \multirow[t]{3}{*}{ AGE GRROUP } & $\begin{array}{l}\text { BETWEEN } \\
\text { GRROUPS }\end{array}$ & 10.058 & 4 & 2.515 & \multirow[t]{3}{*}{6.848} & \multirow[t]{3}{*}{.000} \\
\hline & $\begin{array}{ll}\text { WITH } & \text { IN } \\
\text { GROUPS }\end{array}$ & 89.971 & 245 & .367 & & \\
\hline & TOTAL & 100.030 & 249 & & & \\
\hline
\end{tabular}




\begin{tabular}{|c|c|c|c|c|c|c|}
\hline \multirow{3}{*}{$\begin{array}{l}\text { FIND THE BEST } \\
\text { PRODUCT } \\
\text { ADVERTISMENT }\end{array}$} & $\begin{array}{l}\text { BETWEEN } \\
\text { GRROUPS }\end{array}$ & 3.450 & 4 & .862 & \multirow[t]{3}{*}{2.228} & \multirow[t]{3}{*}{.067} \\
\hline & $\begin{array}{ll}\text { WITH } & \text { IN } \\
\text { GROUPS } & \end{array}$ & 94.839 & 245 & .387 & & \\
\hline & TOTAL & 98.289 & 249 & & & \\
\hline \multirow[t]{3}{*}{ ROCK MUSIC } & $\begin{array}{l}\text { BETWEEN } \\
\text { GRROUPS }\end{array}$ & 1.698 & 4 & .425 & \multirow[t]{3}{*}{.286} & \multirow[t]{3}{*}{.887} \\
\hline & $\begin{array}{ll}\text { WITH } & \text { IN } \\
\text { GROUPS }\end{array}$ & 363.085 & 245 & 1.482 & & \\
\hline & TOTAL & 364.783 & 249 & & & \\
\hline \multirow[t]{3}{*}{$\begin{array}{l}\text { T.V } \\
\text { ADVERTISMENT }\end{array}$} & $\begin{array}{l}\text { BETWEEN } \\
\text { GRROUPS }\end{array}$ & 7.950 & 4 & 1.988 & \multirow[t]{3}{*}{3.636} & \multirow[t]{3}{*}{.007} \\
\hline & $\begin{array}{ll}\text { WITH } & \text { IN } \\
\text { GROUPS }\end{array}$ & 133.930 & 245 & .547 & & \\
\hline & TOTAL & 141.880 & 249 & & & \\
\hline
\end{tabular}

\section{Confectionery product advertisement}

In the above table value of the significant is .000 which is significant and tells that it is significant and alternative hypothesis is accepted and null hypothesis is rejected. It describes that age has impact on this variable.

\section{Age group}

In above table the value of the significant is .000 which is significant and tells that it is significant and alternative hypothesis is accepted and null hypothesis is rejected. It describe that the age has impact on this variable.

\section{Find the best product advertisement}

In above table the significant value is .067 which is insignificant and tells us null hypothesis is accepted and alternative is rejected.it means that age has no effect on this variable.

\section{Rock music}

In the above table the significant value is .887 which is insignificant and tells us that null hypothesis is accepted and alternative is rejected. It means that age has no this variable.

\section{T.V Advertisement}

In above table the value of the significant is .007 which is significant and tells that it is significant and alternative hypothesis is rejected.it describes that age has impact on this variable.

\section{CONCLUSION}

The results are positive. Yes T.V advertisement creates impact on children buying behavior and creates influence of T.V advertisement it is identified with the help of ANOVA and Chi-square test. 


\section{REFERENCES}

[1] Aderson, R., (1995), "Consumer Culture and TV programming", USA: West view Press.

[2] Anderson, R., Engledow, J., Becker, H. (1978), "Advertising attitudes in West Germany and the US.. an analysis over age and time", Journal of International Business Studies, Vol. 9 No.3, pp.27-38.

[3] Bever, T. G., Smith, M. L., Bengen, B., \& Johnson, T. G. (1975), "Young viewers' troubling responses to TV ads." Harvard Business Review, Vol. 53, pp 119-121.

[4] Chauhan, R.M. (1995) "Advertising.. The Ad challenge", Anmol Publication, New Delhi.

[5] Depali (1998), "Children as Consumers", Indian Management, September, pp 78.

[6] Dr. C. Eugine Franco, and Bulomine Regi. S, "ADVANTAGES AND CHALLENGES OF E-COMMERCE CUSTOMERS AND BUSINESSES: IN INDIAN PERSPECTIVE”" International Journal of Research - Granthaalayah, Vol. 4, No. 3: SE (2016): 7-13.

[7] Golden, S. A. R., \& Regi, S. B. Mobile Commerce in Modern Business Era. 